\title{
UMA ANTROPOLOGIA DOS LUGARES E AFETOS
}

\section{Glória Diógenes ${ }^{1}$}

Creio que uma trajetória antropológica inicia-se bem antes da idade adulta. Provavelmente emerge nas primeiras cenas de vida, em cada perplexidade, nas sensações múltiplas de deslocamento e no susto diante do inusitado.

Nasci no Rio de Janeiro. Meu pai, mesmo oriundo do Vale do Jaguaribe, descendente direto de uma oligarquia política marcada pela pistolagem ${ }^{2}$ e pelo "coronelismo, enxada e voto", , decide cursar filosofia e fazer teatro. Em uma de suas apresentações no Teatro Universitário de Fortaleza, conhece uma carioca, de passagem pela cidade, descendente direta de português, aluna da tradicional Escola "Sacre Coeur de Marie" ${ }^{4}$, umbandista e apreciadora das escolas de samba do Rio de Janeiro. Observase que cada um deles já marca em seus itinerários, curiosos sincretismos. Desse enredo amoroso, após o enlace e moradia do casal no Rio, vem ao mundo uma menina, depois de anos de tentativa, filha de uma dupla promessa ritual: missas dominicais na Igreja da Glória e cultos nos terreiros à Iemanjá.

Após quatro anos de vida em Copacabana, o filósofo faz um concurso e, ainda em 1962, assume a carteira agrícola do Banco do Brasil numa pequena cidade do mencionado Vale, denominada Russas. Então, apenas com quatro anos, recordo-me do estupor que senti ao perceber a ausência de luz elétrica, do modo como os homens carregavam, de forma explícita, revólveres e "peixeiras" na cintura, do susto com os "paus-de-arara" que estacionavam em frente à casa, transportando galinhas, cabras, gente, porcos, farinha, leite e uma diversidade de tudo.

Durante parte da minha vida, estive entre férias no Rio, períodos longos numa fazenda denominada Cachoeirinha, bem no coração do Vale, e idas à Capital (Fortaleza, 300 km distante de Russas). Na Fazenda Cachoeirinha, que hoje se encontra submersa

\footnotetext{
${ }^{1}$ Universidade Federal do Ceará, Brasil.

${ }^{2}$ Um dos "balanços" mais elucidativo da minha trajetória, realizado através de uma iniciativa do curso de Comunicação Social e de um projeto idealizado pelo professor Ronaldo Salgado, está na Revista Entrevista número 16, ano de 2005.

${ }^{3}$ Referência ao livro de Vitor Nunes Leal Maia, "Coronelismo, enxada e voto" (1976).

${ }^{4}$ No Rio de Janeiro.

${ }^{5} \mathrm{O}$ nome dado às facas grandes, de uso pessoal, comumente utilizada em trabalhos agrícolas.
} 
pela grande represa do Castanhão ${ }^{6}$, passei parte substancial dos meus períodos de férias. Nos idos da década de 1960, o intervalo escolar era mais ampliado: incluía parte de novembro, os meses inteiros de dezembro, janeiro e fevereiro. Para chegar até a fazenda, viajava quase o dia todo num jipe por estradas carroçais, protegida por um largo chapéu de couro. Essa terra era propriedade de um ex-vaqueiro do meu avô, doada à sua família. O lendário vovô ${ }^{7}$ Bena de Acelino foi comparsa de Lampião nas serras do Pereiro. A casa alpendrada margeava a BR-116. Não havia luz, apenas lampião a gás. Todas as noites, vovó Bena deitava-se na rede e dizia: "Menina, faz uns cafunés que te conto estórias que não tem em livro nenhum da tua escola". E eu fui aprendendo o gosto das narrativas vivenciadas com a intensidade e a passionalidade do corpo. Por vezes, o velho Bena levantava-se da rede e traduzia sagas vividas nas matas "fechadas" do sertão, como se lá ainda estivesse.

Minhas férias eram "produtivas". Plantava milho, feijão, colhia oiticicas, tirava leite das vacas e as tangia na garupa do cavalo do vaqueiro até o açude para que pudessem matar a sede e ali pescava horas a fio. Como não havia televisão, e a cidade mais próxima era muito distante, aproveitava o dia para ler, escrever e conversar com personagens curiosos que visitavam ou circundavam o lugar. Havia a Maria Caipora, "rezadeira" de renome, que mais parecia um xamã. Era grandona, sempre circunspecta, e dizia conhecer a doença "estampada" nos olhos da criatura. Curiosamente, ela se afeiçoou a mim e dizia, nas tantas vezes em que estive observando e perguntando sobre seu interessante ofício, para todos ouvirem - essa menina tem futuro como "rezadeira"8.

Senão exatamente como herdeira dos "poderes" de Maria Caipora, de outro modo sou levada a acreditar que a vivência cotidiana de ritos, crenças, pactos silenciosos que constituíam a vida no sertão, me possibilitaram a abertura de janelas da percepção daquilo que se forma, se enlaça no campo aparente das "pequenas coisas". Não seria esse o chão e a base de um viver e fazer antropológico? Esse encantamento com o mundo parecia estranho em relação ao poder da sedução do que havia sido

\footnotetext{
${ }^{6} \mathrm{O}$ açude Castanhão é uma represa, tecnicamente falando. A barragem está localizada em Jaguaribara, embora atinja outros municípios. A obra foi iniciada em 1995, durante o governo de Tasso Jereissati, e concluída em 2003 numa parceria entre a Secretaria de Recursos Hídricos do Ceará (SRH-CE) e o Departamento Nacional de Obras contra as Secas (Dnocs).

${ }^{7}$ Uma alcunha carinhosa, pois não havia nenhum laço de sangue.

${ }^{8}$ Não apenas Maria Caipora imaginava as vocações potenciais: Weber, no texto "Ciência como vocação", afirma que "Se alguém tem inspirações científicas é algo que depende de um destino que nos está oculto e, além disso, de certos “dons" (2004, p. 10).
} 
deixado para trás. Como diziam minhas tias do Rio: "saiu da cidade mais bonita do Brasil (até o ano de 1960, o Rio era Capital Federal), para morar num "buraco". Acredito que é dessa "teia de significados", aparentemente tão diferenciada, que surgem os primeiros sinais da narrativa antropológica que se segue.

\section{A aventura e o gosto da vida acadêmica}

Em meados dos anos 1970, exatamente no auge dos "anos de chumbo" da cena brasileira, precisei decidir o curso para o vestibular. Vale ressaltar que, nesse momento, meu pai já havia se integrado à $\mathrm{ARENA}^{10}$ e sido eleito deputado estadual nas hostes desse partido. Obviamente, para alguém considerada, nos dizeres da época, estudiosa, aplicada, a profissão escolhida deveria ser do mais reconhecido status social e rentabilidade financeira. Contrariando as expectativas e guiada por uma paixão, decidi ser "aquilo" que um primo "barbudo", sempre correndo de um lado para outro e escondendo livros e discos, havia escolhido como profissão. Obviamente, a primeira observação que escutei da família foi: “Tá ficando doida? Aquilo não é profissão, não, seu primo é apenas um terrorista que contesta o sistema. Não faz nada e nem ganha dinheiro". Essa advertência, em tom de proibição, foi o dínamo que faltava para a escolha definitiva e visceral das ciências sociais.

Ingressei no curso de Ciências Sociais da Universidade Federal do Ceará em 1977. Vale ressaltar que em agosto desse mesmo ano caso, provavelmente para escapar de uma situação opressora na família. Eu e o meu companheiro, nesse momento da alardeada "distensão lenta e gradual ${ }^{11}$ " no cenário político brasileiro, envolvemo-nos com o movimento estudantil e a reabertura dos Centros Acadêmicos, tendo os dois, concomitantemente, tornado-se vice-presidentes dos respectivos centros: o de Ciências Sociais e, no caso dele, o de Medicina. Mesmo tendo de enfrentar muitos reveses, o distanciamento da família e a parca situação financeira, a necessidade de fazer e vender comida em feirinha típica de artesanato $^{12}$, de passar por três gravidezes dentro dos três

\footnotetext{
${ }^{9}$ Ver Cliford Geertz, "Interpretação das culturas" (1989).

${ }^{10}$ Aliança Renovadora Nacional, partido conservador, criado em 1965, com a necessidade de tornar mais sustentável a política do governo militar que assumiu depois do golpe de 1964.

${ }^{11}$ Um processo político desencadeado pelo presidente Ernesto Geisel, de 1974 a 1979.

${ }^{12}$ Havia, na Praça Portugal, uma feirinha de artesanato e comidas típicas, todas as sextas-feiras. Tanto cozinhava como ficava à frente da venda na barraquinha.
} 
anos e meio de graduação e de carregar o codinome de barriguda, considero que fiz um curso muito rico e proveitoso.

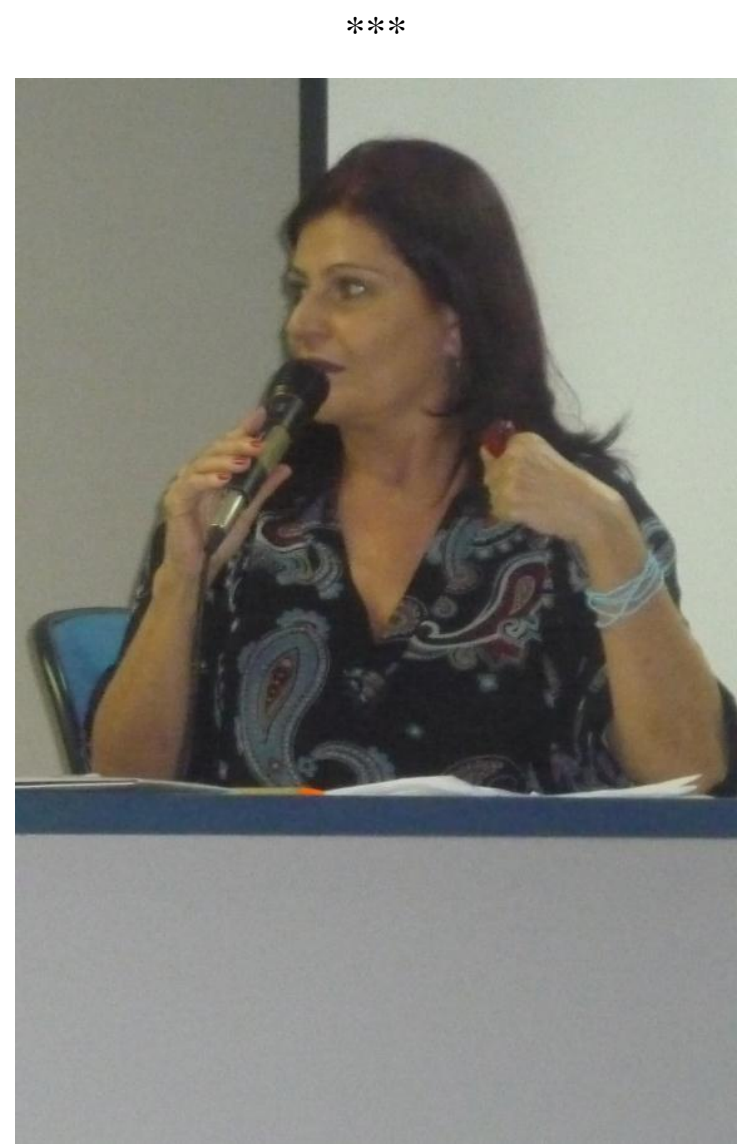

Prof $^{a}$. Glória Diógenes. Foto de 04 de maio 2011. Semana de Antropologia: Imagens e Imagem da cidade. Departamento de Antropologia - UFRN. Coordenação: Lisabete Coradini. Acervo pessoal.

Naquele momento, em 1977, no Ceará, havia pouca ênfase na segmentação das ciências sociais em campos: ciências políticas, sociologia e antropologia. Vivia-se uma rica interface entre teorias e fazeres metodológicos e, desse modo, sempre me considerei uma socióloga "antropologizada" ou uma antropóloga híbrida. Logo no segundo semestre do curso, comecei a participar de uma série de pesquisas organizadas pelo Núcleo de Estudos e Pesquisa Sociais (NEPS) da UFC, dentre elas, uma de extensão nacional - "As estratégias de sobrevivência das populações de baixa renda"13.

\footnotetext{
${ }^{13}$ Coordenada pela professora Teresa Haguette.
} 
Perto de finalizar o curso de Ciências Sociais, o NEPS convida a mim e outra pesquisadora para realizar uma observação antropológica sobre "Parto no meio rural" (financiada pela Fundação Kelllog e pela Maternidade Escola Assis Chateaubriand). O eixo da observação se voltava para a percepção do impacto da introdução de novas técnicas obstétricas no campo das práticas das parteiras rurais. Talvez essa experiência tenha sido o marco inaugural da minha aproximação com o campo da antropologia. Fiz 17 viagens a dois municípios do Ceará - Guaíba e Itaitinga - e logo, logo percebi, nesse caso, a inutilidade de entrevistas e de formas diretas de pesquisa ${ }^{14}$. A mais antiga e emblemática parteira da região, também "rezadeira", me disse logo no início: "Minha filha, não decidi ser parteira, não, isso não é profissão, é uma 'invocação' de Deus, é preciso saber escutar sonhos, você sabe?" Talvez não soubesse mesmo. Quase toda a formação básica do meu curso ocorreu em ares de "abertura" (de 1977 a julho de 1980); Foi marcado por uma avidez de ler e devorar escritos de Marx, Engels e de um séquito de marxistas, até então considerados malditos.

É bem verdade que aceitei essa tarefa de pesquisa munida pela ideia de mapear, inicialmente, os campos e as relações de poder e de dominação constituídos pelo desenvolvimento capitalista no âmbito da medicina. Qual o quê ouvia horas a fio relatos sobre meizinhas para acelerar as dores do parto, chás e ervas "milagrosas", cânticos e orações que pareciam mantras no processo do parto e sempre escutava delas mesmas: “Menina, anota aí o que estou dizendo, que é para você não esquecer". Fui me tornando uma pertinaz narradora. Interessante pensar nessa curiosa analogia; acredito que foi o campo que fez a antropóloga e não o contrário.

No início dos anos 1980, tendo em vista o vertiginoso crescimento das cidades nos anos 1970, fenômenos denominados de "metropolização", "macrocefalia urbana", “inchamento das cidades" e "explosão demográfica” ganham seu ápice. Ao terminar o curso, optei por fazer uma especialização no campo do "Desenvolvimento Urbano e Regional" e voltei meus estudos para um fenômeno típico desses tempos: a remoção de favelas - no caso, o Conjunto São Miguel - e seus impactos nos mundos de vida, mais especificamente, nos arranjos e ocupações de trabalho.

\footnotetext{
${ }^{14}$ Entendi logo depois, e foi preciosa a leitura de Malinowski, nos "Argonautas do Pacífico Ocidental”, a necessidade, para melhor pesquisar, de participar de certos rituais, como brincadeiras, jogos, festas e eventos das comunidades.
}

Iluminuras, Porto Alegre, v.12, n. 28, p. 41-70, jul./dez. 2011 
No segundo semestre de 1982, através da coordenação de André Haguette e Teresa Haguette, ${ }^{15}$ ingressei como pesquisadora no Núcleo de Documentação Cultural da UFC (NUDOC). Participei do Programa de História Oral e da construção de um dicionário biográfico de ex-parlamentares cearenses. Na época pensei: o que uma coisa tem a ver com a outra? Aparentemente, tanto a pesquisa sobre parteiras da área rural, denominada "cachimbeiras", assim como a monografia da especialização e o trabalho desenvolvido através do NUDOC, pareciam mundos cindidos. Em plena era da necessidade da especialização, eu, como uma legítima geminiana, multiplicava e diversificava experiências plurais. Provavelmente, por ter crescido e vivido dentro de um cenário eminentemente político-partidário - dos cabos-eleitorais, das trocas de favores, do compadrio -, por tantas eleições e campanhas vividas pelo meu pai e pelo próprio cenário efervescente do Vale do Jaguaribe, essa experiência precisava, de algum modo, fluir para as ciências sociais. Nessa época, fui ao Rio de Janeiro e aprendi com o Programa de História Oral da Fundação Getúlio Vargas, debrucei-me sobre anais da Assembleia Legislativa do Estado do Ceará e escrevi o livro "As eleições de 1954 e 1958 no Ceará: partidos e eleições"16. Acredito que assim "fechei" um ciclo de vivências e pude registrar e compartilhar um acúmulo pessoal e intelectual de experiências.

No fim do ano de 1983, prestei concurso para professora auxiliar na Universidade Estadual do Ceará (UECE), para o município de Quixadá ${ }^{17}$. Nesse momento, já com dois filhos ${ }^{18}$, passei a ministrar, por seis anos, disciplinas de metodologia do trabalho científico e estudos de problemas brasileiros. Em 1985, ingressei no Mestrado de Sociologia do Desenvolvimento na UFC. Naquela ocasião, no Nordeste, era praticamente impossível se trilhar uma formação acadêmica voltada especificamente para o campo antropológico. A trajetória, fosse do antropólogo, fosse do sociólogo ou do cientista político, ia delineando-se através da escolha dos temas de pesquisa e pelas abordagens teórico-metodológicas utilizadas nos processos de investigação.

\footnotetext{
${ }^{15}$ Teresa Haguette, assim como André, foram grandes incentivadores intelectuais e envolveram-me em pesquisas de grande porte, desde o início do curso.

${ }^{16}$ Editora Styllus/UFC (1989).

${ }^{17}$ É uma cidade situada nos Sertões Centrais distante $167 \mathrm{~km}$ de Fortaleza.

${ }^{18}$ Perdi uma criança na primeira gravidez, em 1978 , no momento de seu nascimento.
}

Iluminuras, Porto Alegre, v.12, n. 28, p. 41-70, jul./dez. 2011 
Logo que entrei no mestrado, ainda em 1986, engajei-me, em Fortaleza, numa pesquisa coordenada pela professora Irlys Barreira, de âmbito nacional: "Estado e movimentos sociais: conflito e participação" ${ }^{\prime 19}$. Pode-se perceber que a experiência inaugural, de natureza nitidamente antropológica, apreendida na pesquisa monográfica sobre as parteiras, foi migrando para um campo de atuação com verniz mais sociológico. Meu tema de dissertação de mestrado, que se inscrevia no bojo dessa investigação nacional, dizia respeito à construção "identitária” dos sujeitos participantes dos movimentos sociais urbanos na relação com o Estado. Participei de muitos encontros de Comunidades Eclesiais de Base (CEBs), acompanhei percursos cotidianos de lideranças femininas da ocupação denominada "Lagamar", reuniões, momentos de conflitos com o Governo do Estado, grupos de estudo da Teologia da Libertação, celebrações diversas e encontros de famílias. No escopo da investigação do mestrado, trouxe de volta o precioso recurso das anotações de campo e a natureza vivencial do ato de pesquisar. Considero que, nos estudos de natureza antropológica, recolhe-se um material mais rico e diferenciado do que o usual "treinamento" de algumas ciências sociais em farejar padrões, regularidades e mapear estruturas. ${ }^{20}$

Infelizmente, não fui liberada pela UECE para realizar o curso de mestrado e muito menos para elaborar a dissertação. Viajava para Quixadá na quinta-feira, ministrava aulas de modo concentrado e retornava no sábado. Era tudo um grande transtorno. Tive de faltar algumas aulas para pesquisar, tanto as do próprio curso do mestrado como outras de minha responsabilidade; tive de driblar o tempo e escrever durante madrugadas e ainda sacrificar muitos domingos e feriados. Ainda no início de 1987, ou seja, no ápice da dissertação, tenho nova gravidez, e minha terceira filha nasce em outubro desse mesmo ano.

Em 1989, sob a orientação da professora Irlys Barreira, finalizei a dissertação e, logo em seguida, fiz concurso para o Departamento de Sociologia da Universidade Federal do Ceará. Parecia um sonho, aqueles que mais se assemelham a prêmios lotéricos. Isso porque, naquele final de 1989, muito raramente, registrava-se a abertura de novas vagas para universidades federais, era necessário alguém aposentar-se para que

\footnotetext{
19 A participação nessa pesquisa propiciou-me a discussão e a participação em vários congressos, seminários e no GT da Associação Nacional de Pós-Graduação em Ciências Sociais (Anpocs), "Lutas urbanas, Estado e cidadania".

${ }^{20}$ Afirmação construída a partir de uma discussão ensejada por Teresa Pires Caldeia no livro "A política dos outros" (1984, p. 27).
}

Iluminuras, Porto Alegre, v.12, n. 28, p. 41-70, jul./dez. 2011 
fosse deflagrado um novo concurso. Além disso, quando se lançava edital para uma nova vaga, a demanda de potenciais professores ultrapassava o campus da UFC e, no geral, agregava candidatos de todo o Nordeste. Felizmente, obtive êxito no concurso e fui contratada como professora assistente I, em janeiro de 1990.

Logo que entrei no espaço universitário, principalmente pelo déficit de professores e pelo acúmulo de ofertas de disciplinas, fui quase "abduzida" para salas de aula. Cheguei a ministrar 20 horas semanais. No início de 1990, tornei-me coordenadora do curso de ciências sociais e acredito ter desenvolvido nessa oportunidade, junto com tantos outros professores, uma significativa renovação de paradigma pedagógico. Criamos um movimento denominado "Ciências Sociais por um novo (per)curso" e abrimos vias de estreitamento entre fazeres acadêmicos e vocações artísticas. No início de 1991, tive outra gravidez, essa bem complicada, que me exigiu meses de repouso absoluto. Em setembro desse mesmo ano, nasce meu último, até então, e quarto filho.

O que interessa tudo isso, quando se trata de um texto de natureza intelectual, acerca da construção de um percurso antropológico? É que sou movida pela ideia de que esses tantos filhos representam parte significativa desse percurso. Primeiramente, foi tornando-se difícil sair e fazer cursos de pós-graduação fora de Fortaleza, e isso me propiciou escolhas interessantes que irei relatar depois, mas, fundamentalmente, fui desconstruindo um discurso usual de que os filhos são opções que não devem coincidir com trajetórias acadêmicas e intelectuais. Obviamente, isso implicou a criação de estratégias diferenciadas de leitura e de produção (muitas vezes amamentei lendo textos e livros amparados por suportes de partituras, semelhantes àqueles utilizados por maestros em concertos). Habituei-me a escrever e preparar aulas assentada no olho do furacão.

Entre 1992 e 1994, iniciei uma série de consultorias e pesquisas de natureza institucional. Construí uma experiência, com alunos das ciências sociais, para a então Secretaria de Ação Social, acerca de histórias de vida de meninos e meninas e um vasto diagnóstico da criança e do adolescente em Fortaleza, para o Conselho Municipal da Criança e do Adolescente. Porém, foi uma dessas investigações que atuou como um marco diferencial nos meus estudos e campo de interesses; uma pesquisa financiada através do $\mathrm{BID}^{21}$, que pretendia, inicialmente, realizar um "censo" de meninos e meninas moradores de rua. Quando percebi o significativo aporte de recursos

${ }^{21}$ Banco Interamericano de Desenvolvimento.

Iluminuras, Porto Alegre, v.12, n. 28, p. 41-70, jul./dez. 2011 48 
financeiros, na qualidade de coordenadora, decidi ampliar o eixo central da pesquisa. Mapeamos os "territórios" diferenciados de práticas e sociabilidades de crianças e adolescentes que viviam nas ruas. Estabelecemos critérios para a identificação de quem deveria ou não ser considerado em situação de moradia de rua - estar na rua mais de oito horas por dia e dormir fora de casa, no que se refere à família de origem, mais de três vezes por semana. Cada pesquisador - eram mais de 60 - deveria registrar, com o sentido da não superposição de registros, além do nome próprio, o apelido de cada um dos meninos e meninas. E foram surgindo tantos novos batismos simbólicos: "Sou o José, conhecido como rato dos bueiros".

A feição do relatório da pesquisa lançada em 1993, denominada "Meninos e meninas de rua: cenário de ambiguidades" ${ }^{22}$, deixou não apenas o BID perplexo com o resultado e o formato do relatório, como os próprios atores implicados na discussão da temática $^{23}$. Isso porque decidimos incluir na pesquisa ${ }^{24}$ não somente as narrativas das novas nomeações, qual seja a história de construção dos apelidos, como também o uso de quatro desenhos, feitos em calçadas, bancos de praça ou mesmo nos momentos de calmaria nas vias de automóveis. O primeiro deveria ser uma representação da casa; o segundo, da família; o terceiro, da rua; e o quarto, uma projeção de futuro, "daquilo que você quer ser". E qual foi a nossa surpresa quando fomos recebendo tantas e tantas folhas em branco do desenho relativo à quarta página. Algumas delas exibiam uma caveira e traduziam o espectro da morte no tempo da vida presente. Era recorrente nessa pesquisa a alusão à participação e a uma filiação simbólica, de sólidos vínculos, a gangues e galeras de rua. Catalogamos um infindável número desses agrupamentos juvenis e pudemos perceber a extensão e a intensidade desse fenômeno na cidade de Fortaleza.

Em meados de 1993, na preparação do projeto de doutorado, decidi estudar o fenômeno das gangues e galeras de rua; a seleção se daria no final de 1993 e o doutorado teria início em 1994. Seria a primeira turma de doutorado em sociologia da Universidade Federal do Ceará. Houve um hiato de tempo proposital entre o fim do mestrado (em 1988) e o início do doutorado em 1994, um intervalo de seis anos. Acho que fiz muito bem em não engatar uma experiência, de forma imediata, na outra. Essa

\footnotetext{
${ }^{22}$ Identificamos 6.300 meninos e meninas em situação de rua e 326 moradores de rua.

${ }^{23}$ Foram aplicados 6.300 questionários e quase $60 \%$ dos meninos(as) diziam que eram mais maltratados em casa que na rua.

${ }^{24}$ Essa via metodológica foi aplicada apenas como meninos e meninas considerados moradores de rua.
}

Iluminuras, Porto Alegre, v.12, n. 28, p. 41-70, jul./dez. 2011 
natureza errática da vida profissional ${ }^{25}$, esse encontro entre temas, lugares acadêmicos, institucionais e vivenciais me possibilitou tecer um olhar em deslocamento, distanciando-me da prática de pesquisa que delimita e confina o "objeto" mesmo que ele assuma novos matizes e ganhe outras configurações.

\section{Uma tese em movimento: cartografias juvenis}

No início de 1994, na qualidade de professora da UFC desde 1990, entro no referido doutorado e, pela primeira vez, sou liberada por quatro anos, mesmo permanecendo em Fortaleza, para fazer as disciplinas e construir o processo de observação e redação da tese. Como relato no livro resultante do doutorado Cartografias da cultura e da violência: gangues, galeras e o movimento hip hop ${ }^{26}$-, iniciei a pesquisa e desde o primeiro ato percebi, mais uma vez, a fragilidade das ferramentas metodológicas que habitualmente utilizamos para os processos de investigação. Isso porque, ao chegar pela primeira vez, ao lado da minha bolsista, moradora dos arredores, no bairro das Goiabeiras e encontrar a "Gangue sem Cérebro" (GSCG), não imaginava o quão inútil pode ser, nesses casos, querer realizar uma conversa pautada em um roteiro "aberto" de entrevistas. As cenas são bastante diferenciadas, mas, de imediato, voltei no tempo e me vi diante da lógica não usual e particularmente inusitada das parteiras do meio rural. Ouvi a recomendação de uma delas: “Anota aí, menina, senão tu vai esquecer”.

Percebi logo na primeira cena de pesquisa, quando diante de mim os integrantes da GSCG disseram que iriam quebrar todo o $\mathrm{ABC}^{27}$ para mostrar "quem se garante" ali, as cancelas metodológicas que teria de ultrapassar. Ora, havia marcado o primeiro encontro na entrada desse equipamento e, quando cheguei, eles ouviam um funk a toda a altura. De modo óbvio, logo vi descer pelo ralo qualquer possibilidade de "fazer entrevistas" ou mesmo de engatar qualquer tipo de comunicação. Desastrosamente, tentando reverter uma situação desfavorável, adverti ao grupo que o alto som do funk estaria impedindo as atividades dentro do $\mathrm{ABC}$. Foi nesse momento que todos se levantaram e decidiram mostrar "quem manda". São os breves lapsos de tempo de um

\footnotetext{
${ }^{25}$ Evoco aqui a autorreferência de Marcel Mauss acerca da sua "dispersão" em relação à variedade de temas estudados. No caso dele, acredito que sua aparente dispersão produziu um olhar menos focado nos processos contingenciais de delimitação de temas de investigação que circundavam sua época.

${ }^{26}$ Editora AnnaBlume (1998).

${ }^{27}$ São projetos do Governo do Estado do Ceará, situados em vários bairros de Fortaleza, que significa "Aprender, Brincar e Crescer".
} 
caso real, de situações-limite, que decidem o modo de inserção de um antropólogo em campo. Poderia ter persistido na farsa da rogativa da diminuição do volume do som para efetuar a entrevista, poderia ter dito quão censurável é destruir um patrimônio público, poderia simplesmente ter me afastado movida pelo temor, mas não. Nesse instante, acho que o espírito das Diógenes do Vale do Jaguaribe "baixou" e simplesmente propus: "Vocês quebram mais tarde, agora podemos conversar?" Acho que essa atitude, pelo menos para mim, fez toda a diferença. Curiosamente, ela me "desarmou" do papel formal da pesquisadora e me deixou mais conectada às circunstâncias de pesquisa.

Depois desse "batismo de fogo" 28 , fui ampliando a teia de encontros com gangues e galeras da cidade de Fortaleza. Passei a frequentar calçadas, terminais rodoviários, estádios de futebol, "peladas" na beira-mar no domingo e bailes funk em bairros diversos da cidade. Como pontuei no capítulo introdutório do livro "Cartografias", a violência rondou meu percurso de vida ${ }^{29}$ e, de algum modo, eu quase

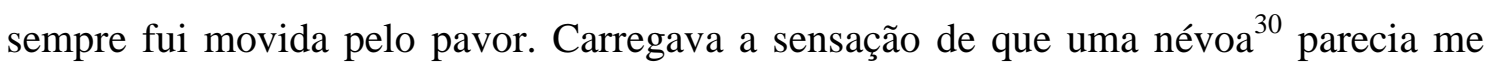
impedir de enxergar, e até mesmo de escutar, o horror banalizado da violência presente nos relatos de tantos jovens. Como no exemplo que tanto saliento, transcorrido numa tarde, no bairro do Pirambu, no momento do encontro com integrantes da Fanáticos Irreverentes Executando Loucuras (FIEL). Um deles me narrou que no dia anterior havia dado um número $\mathrm{x}$ de "furadas",31 no pilantra tal e, de ruim, ele não havia morrido. A tranquilidade com que esse rapaz de no máximo 16 anos relatou o caso, a necessidade, segundo ele, de, depois da "treta" ${ }^{\text {2 }}$, passar pela Catedral de Fortaleza, a Igreja da Sé, e ter uma "conversinha" com Nossa Senhora, a sua revolta "engasgada" do padrasto por ter sido agredido por ele com um fio grosso de iluminação elétrica, a sua devoção pela figura materna, tudo isso ao mesmo tempo, foi conduzindo o meu olhar para a paisagem amalgamada do campo da violência.

\footnotetext{
${ }^{28}$ Livro de Mário Vargas Llosa.

${ }^{29}$ No Vale do Jaguaribe, na Fazenda Cachoeirinha, em Russas, nas campanhas políticas do meu pai, os "cabas" (terminologia usada no sertão) considerados mais perigosos, pistoleiros, homens procurados pela polícia, frequentavam a casa, sendo a maioria deles parentes ou muito próximos da família.

${ }^{30}$ Inspirada em José Saramago no "Ensaio sobre a cegueira".

${ }^{31}$ Através de uma arma branca - a faca.

${ }^{32}$ Gíria utilizada pelas gangues/galeras para nomear brigas, enfrentamentos.
}

Iluminuras, Porto Alegre, v.12, n. 28, p. 41-70, jul./dez. 2011 
Na época, uma orientanda de graduação ${ }^{33}$ decidiu fazer uma pesquisa sobre as imagens que pontuam as representações da juventude, no estudo de caso da Galera da Quadra (GDQ), acerca da violência. Intermediei e participei com ela de uma série de encontros com esse grupo e, por último, foram colocadas na mão de 15 integrantes uma máquina fotográfica descartável para que fotografassem cenas e casos de violência. Como era de se esperar, apenas a metade retornou no dia e na hora combinados com o resultado da captação de imagens e, para a nossa surpresa, não havia nenhuma cena de violência, de agressão, de conflito; absolutamente nada que pudesse figurar como feio ou reprovável. As fotos expressavam as ocasiões mais idílicas possíveis no âmbito cotidiano: o sofá novo da sala adornado por um bichinho de pelúcia, os irmãos banhados e com a melhor roupa pousando na frente da casa, a namorada em várias posições, fotos de mães, avós e deles mesmos. Isso me foi muito revelador. Refleti sobre o "peso" dos conceitos nos trabalhos de campo, tendo em vista que acabam atuando, em algumas circunstâncias, como vendas nos olhos dos pesquisadores. Afinal de contas, a categoria violência não parecia assumir o menor impacto no campo de produção de sentidos e naqueles códigos de linguagem juvenis.

Essas situações vividas na GDQ, na FIEL e na GSCG me alertaram para a precipitação das visões normativas - balizadas no dever ser - que atravessam e movimentam a mentalidade de tantos pesquisadores. Mais do que o risco tão alardeado das pré-noções, as projeções que povoam o imaginário do pesquisador, de como os mundos e atores observados devem se comportar, a ideia preconcebida dos "desvios de comportamento", a percepção do fenômeno da violência como uma mera "quebra" da ordem impossibilita muitos dos antropólogos a realizarem um "mergulho" nas dinâmicas e nas lógicas "internas" dos atores que vivenciam e movem-se dentro dessas práticas. É uma tarefa árdua para um antropólogo sentar-se ao lado de um jovem instigado para um ato de violência, ouvir relatos dos requintes de crueldade com os quais ele deseja um dia usar para eliminar, por exemplo, seu padrasto, sem que o pesquisador incorra no risco de tentar reverter a situação e, desse modo, perder instigantes fios dessa narrativa.

Fui, então, e acredito que esse seja o mérito mais expressivo da minha tese de doutorado, sendo reconhecida entre os jovens de periferia, fundamentalmente os que se

\footnotetext{
${ }^{33}$ Monografia de Maurenízia Andrade Alves, “A violência e suas representações no cenário das gangues em Fortaleza", sob minha orientação, apresentada para o Departamento de Sociologia, da Universidade Federal do Ceará, em 1997.
}

Iluminuras, Porto Alegre, v.12, n. 28, p. 41-70, jul./dez. 2011 
inserem dentro do campo pesquisado, como limpeza. Isso significa, no universo deles, alguém do "lado de lá" que consegue escutá-los e que, nessa escuta, promove um estatuto legítimo de existência tanto à lógica de discurso deles como a deles próprios na condição de sujeitos. Talvez seja essa a única dimensão que faz do ofício do antropólogo uma ação política, "emancipatória"; deixar emergir vozes e narrativas silenciadas ou alteradas pelo jugo imperativo dos conceitos e pelos argumentos de autoridade que povoam a comunidade científica.

Durante o trabalho de campo, por mim autodenominado de "tese em movimento", não apenas encontrei o movimento hip hop como um mediador "de peso", como também passei a ser procurada para falar na imprensa, participar de discussões com várias instâncias do poder público acerca da construção de políticas públicas para a juventude e, durante dois anos, ministrei um curso de ética e cidadania na Academia de Polícia Civil do Ceará. Essa última experiência me possibilitou mediar um campo de aproximação entre setores do movimento hip hop e segmentos mais liberais do corpo policial. Nessa ocasião, o enfrentamento e a agressão praticada pelos policiais aos jovens moradores de periferia atingiam índices alarmantes.

Apenas em alguns períodos precisei isolar-me para escrever a tese. Provavelmente dois fatores propiciaram a possibilidade de uma escritura cravada no coração dos acontecimentos: a primeira diz respeito à própria experiência já adquirida na dissertação de mestrado. Por não ter tido um tempo livre para o intento e tendo-o realizado, mesmo assim, em circunstâncias limitadas, a ocasião de liberação para o doutorado já expandiu e elasteceu a ideia do tempo. A segunda, acredito, deve-se ao fato mesmo dos tantos filhos, gravidezes terem atravessado e povoado a minha vida intelectual e acadêmica. O movimento, a descontinuidade fez parte e é um ingrediente primordial para minhas experiências de criação e produção intelectual.

Em 1998, logo após a defesa da tese de doutorado, é lançado o livro "Cartografias da cultura e da violência". Mesmo com a extensão do livro, ainda existia um farto material inédito, principalmente sobre torcidas organizadas de futebol e bailes funk, que precisava ser ampliado, organizado e escrito. É nesse momento, após o doutorado, que passo a desenvolver uma ampla etnografia dos estádios de futebol, dos bailes funk, complementada, também, com uma observação dos jovens de "classe média”, lutadores de jiu-jitsu, já na condição de bolsista do CNPq. Em 2003, como 
resultado dessa experiência de pesquisa, é lançado o livro "Itinerários de corpos juvenis: o jogo, a festa e o tatame" 34 .

Nesse ínterim, passei a mediar e participar de muitas experiências e ações movimentadas por jovens do hip hop. Havia um vácuo, na minha percepção, que não poderia ter sido preenchido apenas com a tese de doutorado e com pesquisas e outras iniciativas que a sucederam. No início do ano 2000, a Fundação MacArthur ${ }^{35}$ lançava para todo o Brasil um edital de bolsas para iniciativas inovadoras no campo da juventude. Eu inscrevi um projeto sobre "relações de gênero, cultura e violência juvenil", que depois foi ganhando a nomeação pública de "Fazendo Enxame ${ }^{36}$ : oficinas de arte com gangues e galeras de rua”. A aquisição da bolsa e a ida para o Morro Santa Teresinha abrem novos e significativos capítulos no meu itinerário. Vamos a eles.

\title{
Fazendo Enxame: a antropologia tomando corpo
}

A experiência do Enxame possibilita concretizar o que já parecia pulsar e mover toda minha trajetória de pesquisa; um campo vivido, experimentado também pela pesquisadora. É como se à atividade de pesquisar, de forma meramente técnica, faltasse aquela verdade ${ }^{37}$. Essa tendência, que denomino no livro "Itinerários" de "pesquisar com o corpo", pode ser resumida na seguinte passagem:

\begin{abstract}
Não há nesse nomadismo das galeras uma ideia de fixidez, de um espaço para cada coisa, tudo se move e se mistura. O corpo leva e traz maquetes de cidades em movimento. Esse é o maior impacto que realizam o nomadismo das galeras no espaço urbano, mostrar que quem segmenta o espaço é o corpo; sendo assim ele também pode aplainar o espaço, e nesse intento amolecer o próprio corpo para que ele se torne plástico, dobrável, desdobrável, passável. Esse talvez represente um modelo hidráulico de fazer ciência, ao invés de uma teoria dos sólidos, um espaço
\end{abstract}

\footnotetext{
${ }^{34}$ Pela AnnaBlume, em 2003.

${ }^{35}$ Para adaptar os eixos de ação da instituição proponente, elaboramos o projeto: "Relações de gênero, cultura e violência juvenil", aprovado pela Fundação MacArthur. A The John D. and Catherine T. MacArthur Foundation é uma instituição privada que fazia doações para indivíduos e grupos que se propunham a buscar a melhoria das condições humanas relativas a saúde, paz, saúde reprodutiva e ecologia. A fundação apoiava pesquisas, desenvolvimento de políticas, estimulava a criatividade individual e contribuía para o fortalecimento de instituições e lideranças que no geral se projetam fora do âmbito governamental. Nessa seleção havia mais de 700 candidatos para 16 bolsas. Fui uma das agraciadas.

${ }^{36}$ Uma expressão utilizada por galeras que significa causar impacto, provocar medo, fazer balbúrdia.

${ }^{37}$ Refiro-me à discussão empreendida por Cornélia Eckert e Ana Luiza da Rocha acerca dos dilemas da interação no texto "Etnografia: saberes e práticas": "O observar na pesquisa de campo implica na interação com o Outro evocando uma habilidade para participar das tramas da vida cotidiana, estando com o Outro no fluxo dos acontecimentos. Isto implica em estar atento(a) às regularidades e variações de práticas atitudes, reconhecer as diversidades e singularidades dos fenômenos sociais para além das suas formas institucionais e definições oficializadas por discursos legitimados por estruturas de poder". Revista Iluminuras, 2008, p. 4.
} 
liso, dos fluxos [...] uma ciência nômade (Deleuze; Guattari, 1997). Esse tipo de ciência inquieta e desinquieta. Desfaz linhas costumeiras de tráfego, muda roteiros de visitas oficiais à cidade, autoriza, porque legitima, novos fluxos corporais. "Seria preciso opor dois tipos de ciência, ou de procedimentos científicos: um que consiste em 'reproduzir' e o outro que consiste em 'seguir' (Deleuze; Guattari, 1997, p. 39). [...] Que antropologia surge da fusão entre nomadismo, a experiência do ilimitado, o 'desterritorializado' por excelência e o antropólogo que faz do local, do âmbito da vida empírica o limite da sua experiência. [...] Nesse sentido pensar com o corpo, na velocidade de seus enlevos e estremecimentos e a realização de uma filosofia do acontecimento, de uma antropologia que se tece através do corpo do pesquisado. ${ }^{38}$

Desse modo, ao iniciar as oficinas de arte com um grupo mediado pelo hip hop local ${ }^{39}$, aos sábados, já me sentia inspirada na ideia do "seguir" pesquisando "com o corpo". Obviamente, eu pouco ou quase nada entendia de $\operatorname{arte}^{40}$. E, para que os leitores melhor situem essa experiência, reproduzo trechos de uma narrativa publicada na revista Perspectiva, em 2004.

Voltei ao Morro Terezinha em um final de tarde do mês de agosto do ano 2000. Lembro, nesse momento, tudo já era quase setembro. O Sol abrasante, a luminosidade intensa e o mar de um verde-azulado ampliando o céu. Subimos na casa de Sidarta, membro dos Conscientes do Sistema (movimento hip hop), para tentar definir os primeiros passos do projeto. O possível apoio dessa instituição poderia nos garantir realizar uma articulação entre o fazer acadêmico e uma atividade de intervenção mais direta no campo social. A ideia do projeto era utilizar oficinas de arte, com jovens pertencentes às galeras do bairro, como meio de expressão de si, do outro e do grupo e como campo de ressignificação da noção de direitos e cidadania. Ufa! Trocando em miúdos, partíamos da ideia de que a arte é um campo propulsor de significantes: ela certamente irriga territórios esquecidos do corpo, faz emergir novas formas de linguagem. Observamos em uma pesquisa anterior $^{41}$ que as práticas de violência, ao serem narradas, demandam imagens, territorialidades que atuam como suportes materiais da memória. ${ }^{42}$ Ora, esse território pode ser a casa, a esquina do bairro, pedaços da cidade ou mesmo registros efetuados nos corpos dos que evocam lembranças. $\mathrm{O}$ 'ato mudo' ${ }^{43}$ da violência é narrado com o corpo e pontuado por imagens carregadas de história. Formamos o Projeto Enxame inicialmente com 16 (dezesseis) participantes. Utilizando-nos de uma conversa com o grupo, identificamos uma convergência de interesses para as artes visuais (fotografia, grafites, artes plásticas e vídeo). Observamos que, diferentemente do teatro, como havíamos inicialmente planejado, e as oficinas de artes utilitárias, o campo da comunicação visual canaliza dois interesses específicos: uma maior demanda do mercado e uma forma mais mobilizadora das tensões e expressões múltiplas de linguagem do grupo. Foi observado entre as gangues um modo de contar histórias de vida através do corpo, através das marcas. A comunicação visual tornou-se tão recorrente que é como se as palavras

\footnotetext{
38 “Itinerários de corpos juvenis", 2003, p. 25 e 29.

${ }^{39}$ Tratava-se da posse dos "Conscientes do Sistema" cujo líder era o rapper Lobão.

$40 \mathrm{Na}$ condição de participante do Projeto Cidadão XXI Arte, do Instituto Ayrton Senna, depois realizamos uma formação em arte-educação.

41 Ver "Cartografias da cultura e da violência: gangues, galeras e movimento hip hop", de Glória Diógenes (1998).

${ }^{42}$ Ver "Poética do espaço", de Gaston Bachelard (1998, p. 28). Nessa obra, o autor desenvolve a ideia da topoanálise, que seria o estudo sistemático dos locais de nossa vida íntima.

${ }^{43}$ Ver Hannah Arendt (1994), sobre a violência.
}

Iluminuras, Porto Alegre, v.12, n. 28, p. 41-70, jul./dez. 2011 
funcionassem apenas como âncora para que o corpo-linguagem pudesse exibir-se [...] (Diógenes, 1998, p. 191).

Desse modo, alguns referentes foram construindo um quadro norteador do Projeto Enxame: violência juvenil, arte da comunicação visual ${ }^{44}$ e territorialidades (cidade/bairro/corpo). A ideia básica é a de que a arte da comunicação visual, por meio dos suportes materiais da memória (cidade e corpo), pode ser considerada o campo por excelência de expressão e ressignificação de códigos da violência. Sendo assim, organizamos cinco oficinas de imagens: ilustrações escolhidas em revistas acerca das diferenças de gênero, ilustrações de artistas plásticos acerca da história da arte de maior identificação com cada um dos participantes, fotografias dos participantes do grupo tematizadas em "lugares que contam a minha história", "pessoas que contam a minha história" e as "narrações sobre cores, formas e imagens dos grafites". Nas oficinas de fotografias, além do trabalho relativo à "seleção" das lembranças, por intermédio das lentes do olhar do fotógrafo, foi requisitada uma seleção das fotos mais elucidativas de cada participante, a atribuição de um título a cada foto e a construção de um fio narrativo compartilhado com o grupo. Reunir fragmentos de imagens, vestígios de lembranças e tecer fios emaranhados da memória individual na tapeçaria coletiva do grupo. ${ }^{45}$

Todos os sábados, eu subia o morro. Passei a envolver alunos tanto do curso de ciências sociais como de comunicação, psicologia, direito, letras e outros que não me ocorrem à memória. Não havia sede, funcionávamos em um clube abandonado denominado "Terra-Mar". Aos poucos a experiência foi crescendo. Jovens de comunidades e bairros próximos foram se achegando. Participei em 2001 de uma oficina, organizada pelo jornal $\mathrm{O}$ Povo e por entidades que formavam uma rede de defesa dos direitos de criança e adolescente, para que fosse difundida a experiência do "Enxame". O referido jornal publica uma página inteira sobre o resultado da oficina e, surpreendentemente, recebo um telefonema de uma pessoa do Ministério da Justiça pedindo um encontro urgente e sinalizando a vontade de uma parceria técnica e financeira. Como, se não tínhamos uma razão jurídica? Tratamos então, tendo em vista a demanda do funcionamento diário das oficinas, por parte dos jovens participantes, de formalizar e ampliar o projeto. Transformei o "Enxame" em uma experiência de “extensão universitária" e passei a dividir minha carga horária do seguinte modo: manhãs no morro, com exceção de horários de aula e tardes na $\mathrm{UFC}^{46}$.

Posteriormente, alugamos uma pequena casa e ampliamos o grupo para 30 participantes. Tornei-me, junto com o rapper Lobão, "oficineira" da palavra. A

\footnotetext{
${ }^{44}$ Entendo por arte da comunicação visual um conjunto de fazeres criativos cujo suporte é a imagem (forma, cor e movimento).

${ }^{45}$ Revista PERSPECTIVA, Florianópolis, v. 22, n. 2, p. 471-493, jul./dez. 2004. Disponível em: http://www.ced.ufsc.br/nucleos/nup/perspectivas.html. Acesso em: 10 nov. 2011.

${ }^{46}$ Tivemos o apoio do UNICEF, ganhamos um prêmio do Instituto Ayrton Senna - "Cidadão XXI Arte" e ganhamos um prêmio do BNDES - "Transformando em Arte", o que possibilitou a ampliação do projeto.
}

Iluminuras, Porto Alegre, v.12, n. 28, p. 41-70, jul./dez. 2011 
experiência consistia em compartilhar com o grupo de participantes, duas vezes por semana, compositores e autores emblemáticos da produção de poesia e música da língua portuguesa e criar poesias e raps autorais. Passamos por toda a história da música popular brasileira, por poetas como Manuel Bandeira, João Cabral de Melo Neto, Adélia Pardo, Leminski, Drummond, Manoel de Barros e tantos outros. Fui percebendo, pouco a pouco, como esses jovens exprimiam um duplo comportamento: dentro da sede, nas nossas atividades, eram solícitos, entusiasmados, participativos, colaborativos; lá fora, travestiam-se de tantos outros personagens. Na escola ${ }^{47}$, assim como no âmbito das famílias, eram identificados como "pestes", "ovelhas negras", "alunos-problema", compunham o adágio popular muito difundido no Nordeste - pau que nasce torto morre torto. Ouvia amiúde das mães e professores: "Ainda bem que esse menino ou menina entrou no projeto, porque aqui ele não tem jeito". Muitos deles permaneciam dentro desses espaços de sociabilidade, calados e imersos no mais profundo silêncio.

Fui, então, implementando com Lobão e com um grupo que já planejava e criava estratégias conjuntas de atuação, formado por jovens que entraram bem no início, experiências de intervenção, expressão pública e apropriação urbana na cidade de Fortaleza. A primeira experiência foi pensar, junto com diretores e dramaturgos, uma peça de teatro denominado "Um inventário de gestos". A experiência extrapolava a concepção da peça propriamente dita. A ideia era passar um intervalo de seis meses "garimpando gestos" usuais e comunicativos do grupo, através de relatos e anotações, muitas vezes opacas e distorcidas dentro do campo das relações institucionais. Havia um diretor, uma figurinista, cenógrafos, fotógrafo/videomaker, uma assessora de comunicação e produtora, um coreógrafo, um técnico em trilha sonora, iluminador, dois “etnógrafos" $"$, e eu atuando como "roteirista" de primeira mão ${ }^{49}$ e, também, "dando pitaco" em todas as outras áreas. A peça apresentou-se no Theatro José de Alencar ${ }^{50}$, no Teatro do SESC e no Teatro de Guramiranga, município do interior do Ceará.

Em seguida, fomos constituindo uma malha de iniciativas que pretendiam dar visibilidade às ações de jovens da periferia para além do estigma de violentos,

\footnotetext{
${ }^{47}$ Duas psicólogas que acompanhavam o dia a dia do Enxame tantos nas escolas como nas famílias de referência.

48 Uma delas é Abda Medeiros, doutoranda no Programa de Pós-Graduação em Sociologia, da Universidade Federal do Ceará (UFC). Possui pesquisas com concentração em Antropologia Urbana referentes a cidade, juventudes, musicalidades e práticas culturais.

${ }^{49} \mathrm{O}$ "Enxame" reuniu profissionais voluntários das mais diversas áreas de atuação.

${ }^{50} \mathrm{O}$ mais tradicional e antigo da cidade.
}

Iluminuras, Porto Alegre, v.12, n. 28, p. 41-70, jul./dez. 2011 
pichadores, vândalos, destruidores do patrimônio e ameaçadores da ordem pública. Fomos a várias exposições de arte, como a da Rodin, Le Park, a peças de teatro, como a da Tarsila do Amaral, shows de música e, fundamentalmente, criamos ações de impacto na cidade. Cada nova incursão era anteriormente discutida pelo responsável pelas oficinas de história da arte $^{51}$. Provavelmente, se eu fosse descrever as experiências mais específicas do "Enxame", elas iriam ocupar quase todo o espaço desta narrativa. Desse modo, vou centrar em apenas dois casos, apresentados em encontros acadêmicos e publicados em revistas científicas.

A experimentação diz respeito a um conjunto amplo de ações denominado "Cidades e narrativas". A ideia era realizar, em grupo, alguns roteiros urbanos: o do "pichador"; dos que entraram no Enxame para cumprir a medida socioeducativa da liberdade assistida ${ }^{52}$; o percurso do Lobão desde a rua de sua infância, o itinerário de sua participação na "gangue mais afiada do morro" até sua inserção no movimento hip hop; a ida ao Shopping Iguatemi na condição de Enxame, naquele momento o mais elitizado da cidade; os usos da Beira-Mar" ${ }^{53}$ por diferentes jovens; e uma "escuta sonora da cidade" realizada por jovens do Enxame na Av. da Universidade e tantos outros. O roteiro incluía: fotografias ${ }^{54}$ realizadas por quase todos os que faziam o percurso, anotações do percurso (uma espécie de diário de campo) e momentos de conversa e troca de visões e opiniões após realizado esse percurso, já na ambiência da sede.

Aqui, vamos destacar dois percursos: um primeiro publicado na "Revista de Educação AEC",55 e o segundo na "Revista de Política e Sociedade" ". Na primeira, seguimos "os rastros de Lobão":

O corpo de Lobão faz fervilhar imagens do bairro e da cidade. Realizar percursos no bairro, na vibração de um andante/narrador como Lobão, é mover-se através de

\footnotetext{
${ }^{51}$ Igor Câmara, naquele momento aluno do curso de Comunicação Social, esteve desde antes da criação do Enxame, tanto atuando como "oficineiro" de história da arte, de fotografia e vídeo, como também no dia a dia do projeto. Contamos também com a presença da fotógrafa Nely Rosa e da artista plástica Milena Travassos.

52 De acordo com Estatuto da Criança e do Adolescente no seu Art. 118: "A liberdade assistida será adotada sempre que se afigurar a medida mais adequada para o fim de acompanhar, auxiliar e orientar o adolescente. $\S 1^{\circ}$ - A autoridade designará pessoa capacitada para acompanhar o caso, a qual poderá ser recomendada por entidade ou programa de atendimento. $\S 2$ - A liberdade assistida será fixada pelo prazo mínimo de seis meses, podendo a qualquer tempo ser prorrogada, revogada ou substituída por outra medida, ouvido o orientador, o Ministério Público e o defensor".

${ }^{53}$ A principal avenida da orla marítima e uma espécie de cartão-postal de Fortaleza.

${ }^{54}$ Nesse momento, tanto já tínhamos obtido máquinas fotográficas, como havíamos recebido algumas doações.

${ }^{55}$ Revista de Educação AEC, Brasília, 2003.

${ }^{56}$ Universidade Federal de Santa Catarina, v. 5, n. 8, 2006.
}

Iluminuras, Porto Alegre, v.12, n. 28, p. 41-70, jul./dez. 2011 
marcos de experiências que já se encontram cartografadas no corpo. É assim que a cada lugar Lobão assume nomeações diversas: ele é DEF, Palito, Chuchu, Júnior e propriamente Lobão. Interessante a mudança que se efetiva na forma de mover seu corpo, na composição de sua gestualidade nos vários espaços de nomeação: 'Quando entro na minha rua, logo vou soltando meu corpo. Fico todo ameninado, vou deixando de lado esse meu jeito de líder do bairro, não dou conselho a ninguém. Sento na calçada e sei que ali eu sou o Chuchu. Brinco e grito igual aos meus primos, meus amigos "das antiga". Ali não sou modelo pra ninguém, até meu olhar muda. Aqui eu sou um nada, sou o Chuchu, simplesmente o Chuchu, sem compromisso com nada $[\ldots]^{, 57}$

Como elucido no âmbito dessa pesquisa-experimento, através das pistas de Lobão e de tantos outros narradores, rastreamos os caminhos dos corpos na produção dos sentidos de cidade em múltiplas trilhas urbanas. Elas, as trilhas, certamente nos conduziram a espaços fora do epicentro da visibilidade, do tráfego e da concentração de usos de equipamentos e serviços urbanos da metrópole de Fortaleza. Percursos que combinam uma curiosa estética urbana, onde falar em algo significa morar em algo ${ }^{58}$.

A segunda experiência, essa mais especificamente denominada de "escuta nômade", se dá dentro do eixo "Cidades e narrativas" e foi realizada na Avenida da Universidade no segundo semestre de $2004^{59}$. Como ministrava a disciplina de Introdução à Sociologia para o curso de Pedagogia, primeiramente, convidei os integrantes dessa oficina ${ }^{60}$ para assistirem a minha aula no primeiro tempo (de 7 horas às 9 horas). Acho que esse foi o impacto mais significativo dessa experiência. Os oito integrantes do Enxame ficaram perplexos por observarem que a maioria dos alunos e alunas permanecia em silêncio e intervinham pouco em sala de aula. Eu mesma, na condição de educadora, parecia atravessar uma fronteira invisível no duplo papel de “oficineira da palavra", na parceria com um rapper, e de professora universitária. Vamos à próxima trilha:

Iniciamos a caminhada pela Av. da Universidade dia 15 de abril de 2004 às 9:30 da manhã [...] Lila, de posse do gravador, tenta correr na mesma velocidade de um ônibus no afã de capturar seu som. Parecia antecipar a posterior percepção que "cada coisa que você ouve é um objeto sonoro" (Schafer, 1997: 177). Um outro (Mariano) tenta, em vão, fotografar um ônibus em movimento e, nessa luta corporal entre espaço e tempo, Lila opta por dar lugar à sua voz: "Estamos na rua 13 de maio é?

\footnotetext{
${ }^{57}$ Glória Diógenes, “Linguagens da Rebeldia: nomadismo juvenil na cidade”, 2003, p. 90.

58 Juliano Pessanha, "A província da escritura" (2001).

${ }^{59}$ Essa avenida tem na sua extensão vários equipamentos: casas de língua estrangeira, cursos da área de humanidade, inclusive o de Ciências Sociais, restaurante universitário e conservatório de música. É também local de sede de vários partidos, prioritariamente os que se dizem do campo da esquerda, além de ser uma via de intenso tráfego de veículos e de transporte público.

${ }^{60}$ Seis integrantes, além de mim.
}

Iluminuras, Porto Alegre, v.12, n. 28, p. 41-70, jul./dez. 2011 
Não, é na Av. da Universidade, esse é o som do 'cambão' ${ }^{\text {, }}$ que a gente não suporta, mas todo dia eu tenho que enfrentar esse som e ninguém bateu foto do 'cambão", 62

Como fotografar o efeito visual de um som que reflui cotidianamente no imaginário de Lila e dos tantos outros que compartilharam da ideia do "som do cambão que a gente não suporta"? Os ruídos de cada "cambão" que passava na avenida pareciam 'tapar' a audição. Depois de algum tempo, na medida em que outros sons foram sendo escutados, emergiu "a zuada do cachorro", o "barulho da vassoura" na calçada, "uma imagem fotografada de um balão que adorna uma sede de partido e que emite, imaginariamente, sons de 'jingles' de campanhas eleitorais" e, por fim, o "som do vento".

Decidimos, já na parte final de nossa experiência, sair da avenida e chegar a uma pequena rua, de um conjunto de casas de vila, paralela à referida avenida. A narradora citada, Lila, logo diz: “a rua é tão silenciosa que a gente escuta. É o som do vento batendo nas plantas. Parece que a gente tá numa fazenda, é calmo. Parece que eu tô lá em casa sozinha, sem ninguém perturbando, sem minha mãe gritando nos meus ouvidos para varrer a casa". Fui assim compreendendo que, quando apreciamos os sons e as narrativas condensadas na "escuta andante", podemos identificar feixes de ondas provocados pelos movimentos dos corpos no espaço e suas várias interpretações. "A escuta é como uma invisível porta acústica que nos conduz para outras passagens" ${ }^{\text {63 }}$. Após apreciar o burburinho dos oito integrantes no compartilhamento dos sons captados nas ruas, nas imagens fotográficas considero que escuta sonora é uma forma não intencional de "tocar a cidade", de perceber a teia imaginária que recobre a materialidade da vida urbana.

Como se diz no jargão popular, a experiência do Enxame "deu muitos panos para as mangas", qual seja, além do efeito mobilizador ${ }^{64}$ de criação ${ }^{65}$ e da abertura de novas perspectivas para os jovens do projeto, apurou minha acuidade e sensibilidade de pesquisadora e proporcionou essa mesma experiência para muitos alunos da Universidade.

\footnotetext{
${ }^{61}$ Gíria que alguns jovens usam para se referir ao ônibus, transporte coletivo.

62 "A arte de fazer Enxame", Florianópolis, 2006, p. 210.

${ }^{63}$ Idem, p. 217.

${ }^{64}$ Através de um projeto de outro projeto de extensão, criamos, com alunos do curso de Comunicação Social, um programa diário de rap na FM Universitária da UFC.

65 Através dessa experiência e da pesquisa resultante do doutorado, fui construindo a ideia de que a violência é uma força, uma "forma de inserção social às avessas" que pode ser canalizada e recriada através das potencialidades da linguagem artística.
}

Iluminuras, Porto Alegre, v.12, n. 28, p. 41-70, jul./dez. 2011 
No início de 2005, foi eleita prefeita em Fortaleza Luizianne Lins. Naquele momento, tendo em vista o apoio efetivo do Partido dos Trabalhadores (PT) para um candidato do Partido Comunista Brasileiro (PCdoB), acreditava-se que a referida candidata, que iniciou a campanha com $3 \%$ de intenção de votos, jamais iria "derrubar" as fortes máquinas partidárias e os "caciques políticos" locais. Essa candidata catalisava, nesse momento, por seus mandatos de vereadora e deputada estadual, um conjunto de pautas de direitos humanos: dos segmentos da diversidade sexual, mulheres, juventude, etnias, dentre outras. Era uma simpática apoiadora dessa campanha e, para surpresa de todos, Luizianne foi eleita e eu convidada, tendo em vista o trabalho desenvolvido no "Enxame", para o cargo de presidente da Fundação da Criança e do Adolescente (FUNCI), com status de Secretaria da Criança e do Adolescente, depois transformada e ampliada para Secretaria de Direitos Humanos ${ }^{66}$. Esse capítulo de minha trajetória, por ser ainda tão recente, e pouco transformado em narrativa escrita, me levará, aqui, a efetuar o consequente recorte, que fornece o título da secção seguinte.

\section{Uma antropóloga no poder?}

É de se esperar o alvoroço que essa mudança causou na minha vida pessoal. Afinal de contas, tratava-se de assumir um cargo de Secretaria, de acordo com dados do IBGE, da quinta metrópole do Brasil em população. Uma cidade marcada por contrastes e profundas linhas de segregação urbana. Dizia para quem quisesse ouvir que jamais assumiria qualquer cargo administrativo. Nessas minhas falas, ao assistir, algumas vezes, a acirradas disputas para a coordenação da Pós-Graduação em Sociologia na UFC, sinalizava que de mim todos estariam livres, tendo em vista uma inclinação pessoal ao anarquismo.

É, mas outro adágio popular diz: "Nunca fale: 'dessa água não beberei"”. Em janeiro de 2005, lá estava eu sentada num enorme "bureau", inundada de papéis por assinar e acionada por uma torrente de fornecedores, devido a pagamentos atrasados da gestão do prefeito anterior. Não havia nenhum - nenhum mesmo - alimento para os "abrigos" e para os outros espaços de ações implementadas pela instituição. Tive de negociar a entrega de ovo, arroz, feijão, açúcar, qual seja, de todos os gêneros alimentares básicos. Lembro que, quando findei as negociações, me comprometendo a

${ }^{66}$ Ocupei esses cargos públicos de janeiro de 2005 até dezembro de 2010, qual seja, durante seis anos.

Iluminuras, Porto Alegre, v.12, n. 28, p. 41-70, jul./dez. 2011 
realizar todos os pagamentos atrasados ao longo dos três primeiros meses, entrou pela porta uma assessora e advertiu: "Doutora, falta o principal, o gás, e esse é o fornecedor mais complicado, o mais difícil de ceder". E, durante alguns meses, todos os "paradigmas incendiários ${ }^{67, " ~ v o l t a r a m-s e ~ a p e n a s ~ p a r a ~ a ~ m a n u t e n c ̧ a ̃ o ~ d e ~ u m a ~ e s t r u t u r a ~}$ prestes a ruir.

Vale ressaltar que os quase 700 funcionários, tendo em vista que a fundação havia sido criada em 1994, eram terceirizados, não concursados e essa situação promovia a rotatividade de profissionais e o incessante pedido por cargos e "posições" de vereadores e outros personagens da arena política. A flutuação de profissionais, o orçamento limitado para a efetivação da política, a quase inexistente prioridade de pautas relativas à promoção e à defesa de direitos na paisagem de um intrincado conglomerado urbano com déficit de moradia, saúde, saneamento, dentre outros, imprimiu um caráter de luta político-institucional a essa experiência. A tentativa de construção de um modelo baseado nas experiências locais, "costurado" no âmbito das práticas e dos códigos culturais, tomando os sujeitos como partícipes dessa experiência, gerou campos múltiplos de resistência.

Após quatro anos à frente da FUNCI, no segundo mandato da prefeita, em 2009, foi criada a Secretaria de Direitos Humanos (SDH), reunindo as seguintes coordenadorias: Diversidade Sexual, Igualdade Racial, da Pessoa com Deficiência, do Idoso e da Criança e Adolescente. Desse modo, tanto o meu campo de trabalho como de entendimento teve de ser multiplicado por cinco. Instituímos na SDH ações que interconectavam global e local, intervenção, pesquisa e reflexão, direitos constitucionais e "direitos achados na rua" ${ }^{68}$. $\mathrm{E}$ isso tudo colidia com a formalidade das intervenções apreendidas e consolidadas em vários níveis de militância (ecológica, de direitos humanos, de arte-educação, de gênero, de raça, de pessoa com deficiência, dentre outras), qual seja, com a construção prévia de modelos explicativos e de modos de inserção e atuação no campo social.

Como um rápido exemplo do que passa pela mente de antropólogo quando se imagina "poder" intervir nos mundos de vida, criamos um projeto denominado de "Raízes de Cidadania"69. A ideia era realizar, como repetia seguidas vezes, uma

\footnotetext{
67 Titulo do livro de Carlo Ginzburg: "Mitos, emblemas e sinais" (1990).

${ }^{68}$ Roberto Lyra Filho, "O que é Direito" (1985).

69 Eram escritórios de assessoria popular formados por psicólogos, advogados, assistentes sociais, sociólogos e lideranças "locais" atuando na promoção, defesa e difusão dos direitos humanos.
} 
microguerrilha institucional de potencializadas e articuladas iniciativas "locais". O trecho abaixo faz parte de um documento que teve circulação após o meu desligamento da SDH:

\begin{abstract}
Decidimos ter como matéria-prima práticas concretas, insatisfações próprias do lugar e da comunidade, da visão deles mesmos acerca dos seus não direitos. São muitas e tantas as crenças, os hábitos, os costumes, os referentes culturais que acabam travando e dificultando a ampliação e universalização dos direitos humanos. O medo talvez seja o sentimento mais conservador, o que mais produz cancelas, o que mais divide, segrega e exclui. Maria Rita Khell afirma que "as grandes mudanças continuam tendo que vencer a tremenda inércia do medo, das defesas neuróticas e do hábito". O medo é um sentimento passivo, produz sensações de impotência, e a raiva estimula uma reação, um impulso, uma força compulsiva. A percepção de direitos que habita o senso comum parece combinar medo e revolta. "Se o medo pode ser considerado o principal adesivo social, então a raiva - quando sentida coletivamente - é o solvente" (Walton, 2007, p. 68). Uma educação em direitos humanos deve romper com a mera perspectiva de transmissão de valores e de produção de novos comportamentos, deve ter como tarefa precípua mobilizar sentimentos cotidianos que mobilizem energias criativas, agregadoras, de certo modo não racionais de pertencimento, de cuidado e preservação, para que o sujeito se mova na busca e afirmação de seus direitos. ${ }^{70}$
\end{abstract}

Creio que o levar em conta emoções como medo, raiva, revolta, assim como a percepção da importância de sentimentos de pertença no âmbito da promoção dos direitos humanos, provavelmente pontua um modo de concepção típico de uma antropóloga "no poder". Obviamente, essa construção de paradigma dificilmente é decodificada e transmudada em atos do fazer "concreto" institucional. E esse representa apenas um dos tantos entraves. Os demais nem cabem em linhas. Os labirintos burocráticos, a lógica da escassez, os interesses que dirigem a pauta de "prioridades" no uso dos recursos públicos (principalmente quando o assunto ocupa a agenda social) pareciam acontecer quase de modo "exterior" ao sujeito, na forma de "fato social"71. Era essa a sensação: é pouco, ou quase nada, ${ }^{72}$ o grau de autonomia e decisão que

\footnotetext{
${ }^{70}$ Documento escrito por mim, como balanço da gestão, no momento do desligamento voluntário do cargo.

${ }^{71}$ Aqui, faço uma alusão ao pensamento de Durkheim acerca da natureza do fato social, discorrido nas "Regras do método sociológico" (1984). Segundo o autor, "tais fatos são exteriores às consciências individuais e são dotados de um poder imperativo e coercitivo [...] onde cada um é arrastado por todos" P. XXV e p. 8.

${ }^{72}$ Para que não fique a impressão de que "nada foi feito" - e, provavelmente, essa é uma dimensão imaginária decorrente do sentimento de "ressaca" pós-cargo -, devo dizer que efetuamos algumas políticas de impacto "positivo". Como esse discurso mais se assemelha às enfadonhas falas de gestores públicos, estampando conquistas, preferi alocá-las numa nota de rodapé. Aqui, destacaremos apenas alguns desses impactos. Criamos, com apoio da Secretaria de Direitos Humanos da Presidência da República, núcleos da execução das medidas socioeducativas, previstas pelo Estatuto da Criança e do Adolescente em meio aberto - Liberdade Assistida (LA) e Prestação de Serviço à Comunidade (PSC) em todas as Regiões Administrativas de Fortaleza. Municipalizamos essa medida e ampliamos o
}

Iluminuras, Porto Alegre, v.12, n. 28, p. 41-70, jul./dez. 2011 
experimentava no exercício do cargo. Provavelmente, como se vê, meu espírito anarquista, após esses anos de condução de uma complexa política pública, tenha ficado ainda mais aguçado.

Parodiando Marx no Manifesto do Partido Comunista ${ }^{73}$, diria que, na esfera das políticas de natureza governamental, "tudo que é criativo se desmancha no ar". Isso porque as iniciativas que, de forma mais marcante, podem ser consideradas inovadoras, no âmbito dos direitos humanos, "liquefizeram-se" logo após meu afastamento do cargo. De forma esquemática, citarei três dessas "experimentações". A primeira delas diz respeito à criação de um coletivo de arte, denominado de Liquidificador sem Tampa (LST) tinha como objetivo:

O Liquidificador sem Tampa é formado por um coletivo de artistas urbanos. Com o objetivo de utilizar a arte pública como um instrumento educativo e de sensibilização em torno de questões ligadas aos direitos humanos, o Liquidificador sem Tampa vai deixando sua marca na cidade, por onde passa. A metodologia empregada no grupo consiste em quatro etapas. A primeira etapa consiste em conhecer o ambiente, inserindo-se nele, buscando subsídio para elaboração de um conceito que norteará a estratégia de criação da arte pública. A segunda etapa seleciona elementos que têm poder de integração, como pessoas, materiais, lugares, entre outros. A terceira executa a arte pública de modo a criar uma vivência

atendimento de 100 adolescentes para perto de 2000. Inclusive conseguimos incluir atividades artísticas como uma das ações da medida da PSC. Recebemos um prêmio de reconhecimento, em nível nacional, de segundo lugar no Brasil no que se refere à municipalização e ao êxito dessa ação. Criamos a Rede Aquarela, uma política de enfrentamento à exploração sexual, também descentralizada. Criamos um dos primeiros espaços de acolhimento para tráfico de crianças e adolescentes no Brasil, com apoio da Partners of the Americas (http://www.partners.net/partners/default.asp). Nas campanhas de prevenção no carnaval, chegamos a figurar no primeiro lugar como a capital do Brasil que mais denuncia (Disque 100 da SDH - Brasília). Conseguimos incluir Fortaleza no âmbito de uma das cidades mais acessíveis do Brasil; conseguimos, no campo da diversidade sexual, muitas conquistas: LEIS MUNICIPAIS - LEI ORGÂNICA DO MUNICIPIO (LOM) Art. $7^{\circ}$ Compete ao Município: XXI - Criar mecanismos que combatam a discriminação à mulher, à criança e adolescente em situação de risco, às pessoas portadoras de deficiência e de doenças contagiosas, ao homossexual, ao idoso, ao índio, ao negro, ao ex-detento e promovam a igualdade entre os cidadãos. LEI MUNICIPAL N $\mathbf{N}^{\mathbf{0}}$ 8.626/2002 - Esta lei municipal coloca o dia 28 de junho como o Dia Municipal do Orgulho Homossexual. LEI MUNICIPAL N 9.136/2006 (IPM) - Esta lei modifica o texto da lei do Instituto de Previdência do Município, concedendo pensão por morte e auxílio-reclusão ao companheiro ou companheira homossexuais do servidor ou servidora municipal. LEI MUNICIPAL $\mathbf{N}^{\mathbf{0}} \mathbf{8 . 2 1 1 / 9 8} 1^{\circ}$ - Os estabelecimentos comerciais, industriais, empresas prestadoras de serviços e similares, que discriminarem pessoas em virtude de sua orientação sexual, na forma do inciso XXI do artigo $7^{\circ}$ da Lei Orgânica do Município, sofrerão as sanções previstas nesta lei. Lei Municipal 9.548/2009 - Institui na semana do dia 17 de maio a Semana Janaína Dutra a ser trabalhada nas escolas municipais; Lei Municipal 9.573/2009 - Institui no município de Fortaleza o dia 29 de janeiro como o dia da "Visibilidade Trans"; Lei Municipal 9.572/2009 - Institui no município de Fortaleza o dia 29 de agosto como o dia da "Visibilidade Lésbica"; Portaria 01/2010 da Secretaria de Assistência Social (Semas) - Estabelece o direito ao uso e tratamento pelo nome social às travestis e transexuais, no âmbito dos serviços da política municipal de assistência social; Portaria no 03/2010 da Secretaria Municipal de Educação (SME) - Tem como objetivo combater a discriminação à população LGBT e promover respeito à dignidade, possibilitando que cada pessoa se apresente à sociedade com o nome que desejar.

${ }^{73}$ Karl Marx (1990). 
compartilhada. A quarta e última etapa está mais ligada à invenção dos meios de comunicação, acompanhadas de vídeo-instalações, apresentadas em museus e galerias, ou lançadas na internet. ${ }^{74}$

O LST era formado por artistas-educadores que atuavam dentro dos vários programas e projetos da SDH, congregando ainda uma gama diversa de instituições governamentais e não governamentais. A segunda experiência, denominada "Ler é ter direitos", pretendia:

[...] transversalizar ações que já existiam no campo da leitura e narração, potencializá-las e torná-las abrangentes é tarefa prioritária do programa Ler é Ter Direitos. Elas devem alcançar, paulatinamente, todos os territórios da cidade de Fortaleza. Contribuir para a construção de uma política do livro e da leitura ultrapassa a perspectiva binária da estética versus ética, beleza versus cidadania. $\mathrm{O}$ Ler é Ter Direitos pretende apenas mobilizar pulsões imaginárias, ultrapassar o campo restrito das repetições de universos simbólicos que se movem para a sedimentação do isolamento e da indiferença. Ler é recriar, é inventar novas possibilidades, é saber o que nos forma e nos pertence, é compor novas rotas e narrativas de vida. ${ }^{75}$

Observa-se, nas duas iniciativas acima mencionadas, a "leveza insustentável"76 de um antropólogo tentando intervir para além do "frio" e engessado das ações prescritas em lei. A terceira iniciativa - provavelmente a última aqui elencada - é a que mais expressa a performance de uma antropólogo no desempenho de um cargo público. Ela se reporta à produção de um método de "diagnóstico participativo", criado por nós, denominado Mapas de Imagens e Representações de Encontros (MIRE). Ele consistia num dilatado mapeamento de representações e imagens, conduzido pela própria população, acerca de algumas tensões, demandas e violações de direitos vivenciadas em comunidades distintas. Foram realizados alguns "MIRE"; um deles, por exemplo, teve como cenário a "exploração sexual":

Vinte e cinco adolescentes do Mucuripe, Caça e Pesca, Morro Santa Teresinha e proximidades começam amanhã (3) a participar de um projeto de prevenção à violência sexual. Trata-se do Mire (Mapa de Imagens e Representações de Encontros) na Cidade, metodologia desenvolvida pela Coordenadoria da Criança e do Adolescente (Funci) da Secretaria de Direitos Humanos de Fortaleza (SDH). As atividades terão como local de referência a Associação Curumins e acontecem às terças, quartas e quintas, à tarde, até o mês de novembro. Com o Mire, os adolescentes redescobrem os bairros onde moram, através de histórias de vida e fotografias "pin hole" (também chamadas de "fotos de latinha"). O conhecimento da

\footnotetext{
${ }^{74}$ Site da Prefeitura de Fortaleza: http://www.fortaleza.ce.gov.br/sdh/index.php?option=com content\&task=view\&id=75\&Itemid=105

${ }^{75} \mathrm{http}$ ://www.fortaleza.ce.gov.br/index.php?option=com_content\&task=view\&id=13244\&Itemid=239 ${ }^{76}$ Referência ao livro de Milan Kundera, "A insustentável leveza do ser" (1985).
} 
comunidade e o fortalecimento da identidade fazem parte do método para que os adolescentes colaborem com a construção do Plano Operativo Local do Pair. ${ }^{77} 78$

Provavelmente tenha sido essa a parte mais "engasgada" e mais árdua de ser aqui narrada. Tanto meu pedido de afastamento (dezembro de 2010), assim como o retorno à universidade, são ocorrências recentes. A meu ver, essa situação produz algumas complicações que restringem essa via da trajetória. A primeira delas diz respeito a uma dimensão ética: como construir uma visão crítica acerca de uma experiência da qual fiz parte e, mesmo com a minha saída, ainda não teve o seu ciclo concluído? E a segunda aponta a fragilidade de um processo em que somos nós, e não o outro, o sujeito central da observação e da narração. Certamente as passagens aqui esboçadas representam o rascunho de um texto intrincado ainda a ser digerido, elaborado e explicitado, futuramente, em outras palavras.

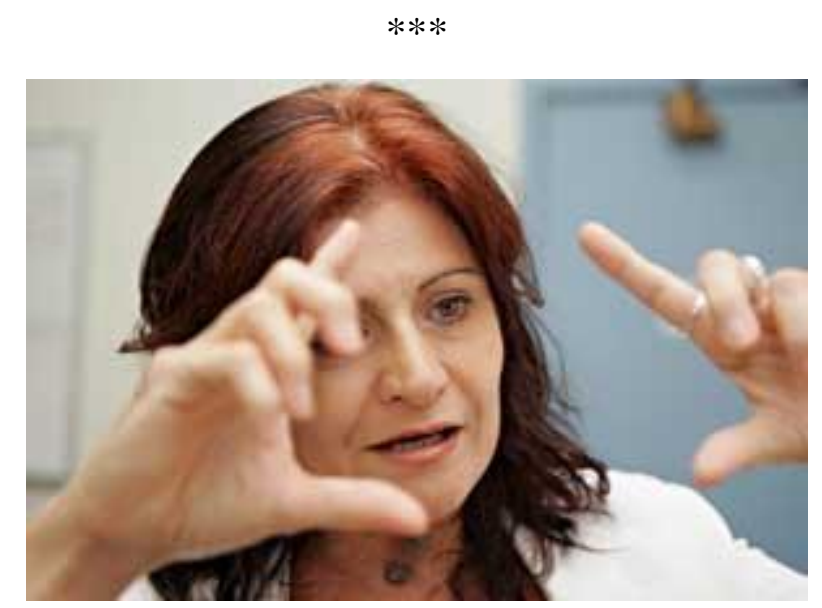

Prof $^{\text {a }}$. Glória Diógenes. Foto publicada no Jornal Diário do Nordeste, em 10 de julho de 2008.

$* * *$

\section{Os tempos de agora, e nem tanto}

Como o presente é um lugar de bifurcação de tempos e lugares, deixamos para o final o relato de atividades que tiveram início anteriormente e que ocupam, nesse momento, parte significativa de minhas atividades. Retornar à universidade me provocou um prazeroso alvoroço. A sensação de liberdade de, novamente, poder emitir opiniões sem o "peso" da representação de um projeto político coletivo, a convivência

\footnotetext{
${ }_{78}^{77} \mathrm{http}: / / \mathrm{www}$. fortaleza.ce.gov.br/index.php?option=com_content\&task=view\&id=13954\&Itemid=78

78 O Programa de Ações Integradas e Referenciais de Enfrentamento à Violência Sexual Infanto-Juvenil no Território Brasileiro (PAIR) é parte das ações desenvolvidas pela Secretaria de Direitos Humanos da Presidência da República.
}

Iluminuras, Porto Alegre, v.12, n. 28, p. 41-70, jul./dez. 2011 
cotidiana com os alunos, o retorno visceral ao campo de pesquisa, me injetaram um ânimo novo. Vale ressaltar que, em nenhum momento, interrompi pesquisas, orientações $^{79}$, envolvimentos em congressos, seminários, outras atividades acadêmicas e o ritmo das publicações. Porém, ler um livro sem pressa, demorar o tempo necessário em campo para ativar sentidos e deixar fluir a observação e ter espaço para discussões teóricas foi uma dádiva sem precedentes.

Ainda na Funci - embora nesse momento tenha abdicado da Bolsa de Produtividade do $\mathrm{CNPq}^{80}$, uma perda ainda não recuperada -, constituí em 2005 o Laboratório de Estudos e Pesquisas da Criança e do Adolescente (LEPCA). Capacitamos educadores que atuavam nas ruas e tinham formação no campo das ciências humanas, realizamos os já mencionados MIRES, pesquisas de pequeno porte, assim como uma investigação mais ampla sobre exploração sexual de crianças e adolescentes denominada "Os sete sentimentos capitais" 81.

Esse livro ${ }^{82}$, afora outra pesquisa anteriormente realizada sobre a mesma temática ${ }^{83}$, além da atuação como gestora, solidificou não apenas a minha inserção nessa área, como também apontou um modo diferenciado, tendo em vista a predominância da abordagem antropológica, de realização de pesquisas institucionais. Tornei-me uma das formuladoras do projeto ViraVida ${ }^{84}$, programa do conselho nacional do SESI e sua consultora nacional em $2008^{85}$.

No retorno à universidade, passei a ministrar disciplinas voltadas para a leitura dos autores clássicos das ciências sociais (Marx, Weber, Durkheim) para a pós-

\footnotetext{
${ }^{79}$ Orientei, de 2005 a 2010, três monografias, cinco teses de doutorado e três dissertações, afora a participação em inúmeras bancas.

${ }^{80}$ Conselho Nacional de Desenvolvimento Científico e Tecnológico (CNPq) é uma agência do Ministério da Ciência e Tecnologia (MCT) destinada ao fomento da pesquisa científica e tecnológica e à formação de recursos humanos para a pesquisa no País.

${ }^{81}$ Combinamos um extensivo estudo exploratório nos pontos diferenciados de exploração sexual em Fortaleza, com um trabalho etnográfico de seis meses, aplicação de questionários e grupos focais. $\mathrm{O}$ trabalho resultou em um livro publicado pela Annablume em 2008.

${ }^{82}$ Foi lançado no III Congresso de Enfrentamento da Exploração Sexual de Crianças e Adolescentes em 2008, no Rio de Janeiro e, posteriormente, transformado em peça de teatro pelo Instituto Ensaio Aberto, sediado no Rio de Janeiro. O espetáculo foi dirigido por Luiz Fernando Lobo e pela atriz Tuca Moraes.

${ }^{83}$ “Criança infeliz” (1998).

${ }^{84}$ Site do programa ViraVida: http://www.viravida.org.br/

${ }^{85}$ Ficou muito difícil combinar o cargo com a atividade de consultoria; de outro modo, a própria assessoria da prefeita de Fortaleza achou oportuna a minha participação, tendo em vista que o ViraVida se inicia em Fortaleza, tendo como parâmetro inicial a experiência e a formulação acumulada em torno da temática no âmbito da nossa gestão (Prefeitura).
}

Iluminuras, Porto Alegre, v.12, n. 28, p. 41-70, jul./dez. 2011 
graduação. Interessante vivenciar a importância de "(re)ler os clássicos" ir e voltar, sair e retornar, de modo diferente, à mesma experiência e enxergar dimensões que pareciam opacas ao olho e a imaginação. Na graduação, estive à frente de algumas disciplinas optativas interligadas à minha área de pesquisa: juventude, cidade, cultura, arte e, mais atualmente, redes sociais. Interessante perceber a afluência intensiva de estudantes interessados em discutir, pesquisar e atuar nas linhas de pesquisa acima mencionadas. Elaborei um projeto de pesquisa, submetido ao departamento de Ciências Sociais, e aprovado logo no primeiro semestre de 2011, que tem como objetivo perceber de que modo se constituem os fluxos de "afectos" juvenis de na paisagem da Internet. Tenho realizado, com toda a polêmica que envolve o uso do termo, juntamente com alguns alunos da graduação e da pós, uma "etnografia virtual" 87.

Esse novo desenho do lugar de exílio temporário atuou como uma espécie de reterritorialização ${ }^{88}$ de um plano mais extensivo de vida. Retornar à universidade assumiu a natureza do chegar, a saga do viajante em terras estrangeiras. Senti circular a adrenalina inicial que atiça as descobertas e os rituais de passagem. Provavelmente tenha sempre me sentido itinerante, na forma de sentir e produzir ciência ${ }^{89}$. Como pontuam Deleuze e Guattari, o nômade pode ser chamado o desterritorializado por excelência - isso significa dizer que ele se reterritorializa na própria desterritorialização (1997, p. 53). Pode parece complicado, mas para mim a imagem é muito nítida e tem uma profunda ligação com o desassossego que me acompanhou e me segue tempos afora.

Ouvi durante toda a minha vida, até mesmo dos filhos, o comentário: "Essa criatura não tem sossego, não". Aqui, no Nordeste, existe uma expressão nativa similar que diz: "Parece que tem um "firvião", E tenho mesmo. Pensava em sair da SDH, aposentar-me da UFC (tenho tempo para isso) e migrar para a arte e a literatura. Ia

\footnotetext{
${ }^{86}$ Segundo Ítalo Calvino, no livro "Por que ler o clássicos?" (1985). Trata-se daqueles livros dos quais dizemos sempre "estou relendo" e nunca estou lendo. Além disso, eles trazem em suas análises e histórias de vida as marcas das leituras que os precederam e retratam a cultura por onde passaram e vivenciaram.

87 Apresentamos um resultado parcial dessa pesquisa no Encontro da Associação Nacional de PósGraduação em Ciências Sociais (Anpocs), em outubro de 2011, GT01 - Ciberpolítica, ciberativismo e cibercultura. Houve uma polêmica em torno da validade metodológica do uso do termo etnografia para pesquisas realizadas no âmbito da Internet. Além as Anpocs, apresentamos parte dessa pesquisa, também, no Observatório da Juventude da Universidade Federal Fluminense, em setembro de 2011.

${ }^{88}$ Ver Deleuze e Guattari em "Mil Platôs", v. 5, 1997.

${ }^{89}$ Quero destacar um precioso trabalho de pesquisa etnográfica realizado por José Machado Pais, denominado "Nos rastos da solidão" (2006). Como ressalta o autor, "as ciências sociais exploram muito o 'objectivo' e o 'subjectivo', mas muito pouco o 'trajectivo', feito de contatos, aproximações, trajectos, deambulações".
} 
tentar um curso de audiovisual e oficinas de criação literária. Narrar sem notas de rodapé, sem a camisa de força da $\mathrm{ABNT}^{90}$; pensar, ler e pesquisar fora de horários prescritos pelo relógio e pelo calendário. Talvez seja esse o sonho de todos os "espíritos livres"91. Viver sob o olho do furação, sob o gosto bom do firvião. Não desisti. Imagina? Há uns três anos, criei um blog literário ${ }^{92}$ e tenho, timidamente, publicado contos e poemas. Preciso, cada vez mais - e percebi essa interconexão em vários textos de Marx, Goffman e Weber -, fundir narrativas antropológicas a relatos literários.

A imaginação é uma pedra preciosa e precisa ser lapidada. Atualmente, tenho duas netas. E posso dizer, sem medo de parecer boba, que, quando assistimos juntas aos vídeos do Peter Pan, assim como elas, temo a presença "odiosa" do Capitão Gancho, o pirata que não admite a existência da "Terra do Nunca". Creio, hoje, que voltei e estou onde deveria estar. Numa nova terra. Não seria a antropologia esse lugar de morar e viver com o corpo os lugares inomináveis das experiências?

\section{Referências}

ALVES, Maurenízia Andrade. A violência e suas representações no cenário das gangues em Fortaleza. Trabalho de monografia apresentada ao Departamento de Sociologia da Universidade Federal do Ceará, 1997, mimeo.

ARENDT, Hannah. Da violência. Rio de Janeiro: Relume-Dumará, 1994.

BACHELARD, Gaston. A poética do espaço. São Paulo: Martins Fontes, 1998.

CALDEIRA, Teresa Pires. A política dos outros. São Paulo: Brasiliense, 1984.

CALVINO, Ítalo. Por que ler os clássicos. São Paulo: Companhia das Letras, 1985.

DELEUZE, Gilles; GUATTARI, Félix. Mil Platôs: capitalismo e esquizofrenia, v. 5. Tradução de Peter Pál Pelbart e Janice Caiafa. São Paulo: Ed. 34, 1997.

DIÓGENES, Glória. As parteiras 'cachimbeiras' no meio rural. Fortaleza: Fundação Kellog/ UFC, 1980, mimeo.

. As eleições de 1954 e 1958 no Ceará: os partidos e suas lideranças. Fortaleza: UFC/ Styllus, 1989.

Meninos e meninas de rua: cenário de ambiguidades. Fortaleza: BNDES/Secretaria do Trabalho e Desenvolvimento Social, 1993.

Criança infeliz: pesquisa sobre exploração sexual comercial de crianças $e$ adolescentes. Fortaleza: Pacto de combate ao abuso e exploração sexual de crianças e adolescentes, 1998.

\footnotetext{
${ }^{90}$ Associação Brasileira de Normas Técnicas.

${ }^{91}$ Termo usado por Nietzsche no livro "Humano, demasiado humano". Segundo o autor, "não é próprio da essência do espírito livre ter opiniões mais corretas, mas sim ter se libertado da tradição, com felicidade ou com fracasso. Normalmente, porém, ele terá do seu lado a verdade, ou pelo menos o espírito da busca da verdade: ele exige razões; os outros, fé” (2000, p. 157).

92 http://linhasaovento.blogspot.com/
} 
Cartografias da cultura e da violência: gangues, galeras e o movimento hip hop. São Paulo: Annablume, 1998.

"Imagens e narrativas: registros afetivos". In: PERSPECTIVA, v. 22, n. 2, jul./dez. 2004. Florianópolis: Núcleo de Publicações do CED/ UFSC, 2004. p. 471-493. Disponível em:

http://www.ced.ufsc.br/nucleos/nup/perspectivas.html. Acesso em: 10 nov. 2011. - Itinerários de corpos juvenis: o tatame, o jogo e o baile. São Paulo: AnnaBlume, 2003.

"Linguagens da rebeldia: nomadismo juvenil na cidade". In: Revista da Educação AEC. Brasília: Salesiana, 2003.

. "A arte de fazer Enxame: experiências de ressignificação juvenil na cidade". In: Revista de Sociologia Política, v. 5, n. 8. Florianópolis: Programa de Pós-Graduação em Sociologia Política / UFSC, 2006.

Os sete sentimentos capitais: exploração sexual de crianças e adolescentes.

São Paulo: AnnaBlume, 2008.

DURKHEIM, Emile. As regras do método sociológico. São Paulo: Ed. Nacional, 1984.

ECKERT, Cornélia; DA ROCHA, Ana Luiza. "Etnografia: saberes e prática". In:

Revista Iluminuras, v. 9, n. 21. Porto Alegre: Publicação Eletrônica do Banco de Imagens e Efeitos Visuais, NUPECS/LAS/PPGAS/IFCH e ILEA/UFRGS, 2008.

GEERTZ, Cliford. A interpretação das culturas. Rio de Janeiro: Guanabara Kogan, 1989.

GINZBURG, Carlo. "Sinais: raízes de um paradigma indiciário". In: Mitos, emblemas, sinais: morfologia e história. São Paulo: Companhia das Letras, 1990.

KHELL, Maria Rita. "Elogio do Medo". In: NOVAES, Adauto (org.). Ensaios sobre o medo. São Paulo: Senac, 2007.

KUNDERA, Milan. A insustentável leveza do ser. Rio de Janeiro: Nova Fronteira, 1985.

LEAL, Victor Nunes. Coronelismo, enxada e voto. São Paulo: Alfa-Omega, 1976.

LYRA FILHO, Roberto. O que é Direito. São Paulo: Brasiliense, 1985.

MALINOWISKI, Bronislaw. Argonautas do Pacífico Ocidental. Rio de Janeiro: Record, 1997.

MARX, K.; ENGELS, F. Manifesto do partido comunista, $3^{\text {a }}$ ed. Petrópolis: Vozes, 1990.

NIEZSTCHE, Friedrich. Humano, demasiado humano: um livro para espíritos livres. São Paulo: Companhia da Letras, 2000.

PAIS, José Machado. Nos rastos da solidão. Lisboa: Ambar, 2006.

PESSANHA, Juliano. "A província da escritura". In: Certeza do Agora. São Paulo: Atêlie Editorial, 2002. p. 24-35.

SCHAFER, Murray. O ouvido pensante. São Paulo: Unesp, 1997.

WALTON, Stuart. Uma história das emoções. Rio de Janeiro: Record, 2007.

WEBER, Max. Ciência e política: as duas vocações. São Paulo: Cultrix, 2004.

Recebido em: 10/05/2011

Aprovado em: 12/08/2011 